The Journal of Animal \& Plant Sciences, 31(1): 2021, Page: 53-60

ISSN (print): 1018-7081; ISSN (online): 2309-8694

\title{
INFLUENCE OF LOCATION ON NUTRIENTS COMPOSITION OF CAMEL BROWSE VEGETATIONS
}

\author{
A. A. Khaskheli ${ }^{*}$, M. H. Baloch ${ }^{2}$, M. I. Khaskheli ${ }^{3}$, G. B. Khaskheli ${ }^{4}$, A. J. Khaskheli5 and A. A. Khaskheli ${ }^{6}$ \\ ${ }^{1}$ Department of Animal Nutrition, ${ }^{2}$ Department of Livestock Management, ${ }^{3}$ Department of Plant Protection, ${ }^{4}$ Department \\ of Animal Products Technology, ${ }^{5}$ Department of Biotechnology, ${ }^{6}$ Department of Poultry Husbandry, Sindh Agriculture \\ University, Tando Jam, Pakistan \\ *Corresponding author’s email: khaskhelias@gmail.com
}

\begin{abstract}
The camel is a typical animal whose preference for browsing depends on the forage species, amount and nutritional quality of the plant. We hypothesize that the quality and availability of forages for camel feeding is influenced by multiple environmental and anthropogenic factors including the composition and structure of grazing land. Current study was therefore themed to assess the locational influence on major nutrients among camel browse vegetations at desert, irrigated and coastal zones of Sindh province. Study was conducted into two phases. Phase one was included to monitor and collect the samples of camel browse vegetations from all three zones of Sindh province, while in second phase samples were analyzed at the Laboratory for the major nutrients. Obtained data was analyzed by statistical procedure i.e. randomized complete block design under factorial models for observing the significant variations among the variables within districts as well as between vegetations. Results indicated desert area (Mithi) possessing negative effect on moisture and positive on the dry matter. Organic matter of Salvadora oleiodes $(79.80 \%)$ was more favored at irrigated area (Tando Allahyar), while inorganic matter (40.60\%) was supported at desert (Mithi). Prominent effect was also observed on ether extract of Prosopis juliflora at Tando Allahyar and Acacia nilotica at Mithi at irrigated area though pertained significantly higher values. Nitrogen free extract and total carbohydrate of Salvadora oleiodes at desert and coastal area was recorded significantly low compared to irrigated. Crude fiber in Salvadora oleiodes (23.80\%) was more favored at coastal area, but not at the desert. Study concludes that the location significantly influences the nutrients composition of camel browse vegetations. Desert area negatively affect the moisture content and positively the dry matter, inorganic matter and ether extract contents. The organic matter and crude protein contents are more favored at irrigated area, while coastal area support the concentration of crude fiber.
\end{abstract}

Keywords: Coastal zone, Forage preference, Location, Nutrient, Camel

https://doi.org/10.36899/JAPS.2021.1.0192

Published online August 26, 2020

\section{INTRODUCTION}

In Pakistan 68 million hectares area is categorized as arid, semi-arid and desert, while from that area, rangelands are stretched on approximately 49 million hectares (Majeed et al., 2002). A great diversity of plant species, composition, structure, productivity and ultimately their capacity to support the camel husbandry has been observed at these rangelands.

It has been reported that globally about 120 million pastoralists depend on rangelands, while upholding more than $5000 \mathrm{M}$ ha of rangelands (Joshi et al., 2013). These rangelands are a great sink of carbon, as it stores up to $30 \%$ of the world's soil carbon (Tennigkeit and Wilkes, 2008). These rangelands are presently facing a myriad of challenges such as over grazing, massive erosion, land use change, encroachment and climate change (Dong et al., 2009). It is very important to use rangelands justifiably for the proportionate supply of forages to the livestock animals including camels. Camels generally depend on the natural vegetations for nutrients supply. They are fed green fodder and hay straw in the irrigated plains along with concentrate feed. In mountainous areas top feeds like Acacia nilotica, Morus alba, Zizyphus jujuba etc are offered (Younas and Yaqoob, 2005). There is a common saying in Rajasthan for camel feeding that the camel eats everything except Aak (Calotropis procera). Generally, camel prefers to browse high moisture vegetations such as Prosopies sineraria, Zizyphus nummularia, Callygonum polygonodes during summer season but during the rainy season, the plants rich in electrolytes and oxalate content like Capparis deciduas and Lasirus sindicus are preferred (Iqbal, 2005; Chaudhary and Houérou, 2006).

Plant preference by camels depends on several factors like plant species, nutritional quality of the plant, moisture percentage, taste, aroma and the amount of forage (Shaheen, 2009). Additionally, the physical environment, plant environment and animal behavior also have significant influence on the selection process during browsing (Iqbal and Khan, 2001). We hypothesize that the location of plants may also has significant effect on 
the nutrients composition and ultimately camel browsing behavior. Regarding the availability, distribution, nutrients composition of camel browse vegetations although various studies have been reported from different parts of the world, but in Sindh Province of Pakistan there is a gap which needs investigation. Current study was therefore planned in order to focus different camel browse vegetations in Sindh Province of Pakistan at desert, irrigated, coastal areas for observing the locational effect on nutrients composition of camel browse vegetations.

\section{MATERIALS AND METHODS}

Location of study: The research project was carried out in two parts. The first part was the screening and sampling of camel browse vegetations, whereby three different districts i.e. Mithi, Tando Allahyar and Thatta from sandy desert, irrigated and coastal camel habitat zones of Sindh province were focused. Second part of study was conducted at the laboratory of Animal Nutrition, Faculty of Animal Husbandry and Veterinary Sciences, Sindh Agriculture University, Tando jam, whereby collected samples were brought to the laboratory for analysis of major nutrients.

Experimental design: Current research was conducted during the year 2018, whereby investigation was subjected into two phases. In the first phase, comprehensive survey was performed at three different districts i.e. Mithi, Tando Allahyar and Thatta of Sindh province in order to collect such camel preferred vegetations which are commonly found in all three zones for camel browsing. Using a pretested questionnaire, camel herders from each district were inquired about availability and preference pattern of camel browse vegetations. A total of five $(\mathrm{n}=5)$ common camel browse vegetations (Acacia nilotica, Ziziphus nummularia, Prosopis juliflora, Salvadora oleiodes and Capparis deciduas) were selected from one district of each three zones of Sindh Province i.e. Mithi (desert), Tando Allahyar (irrigated) and Thatta (coastal mangroves) and sampling was performed in order to examine the influence of location on major nutrients like moisture, dry matter: organic matter and inorganic matter, crude protein, ether extract, total carbohydrate: nitrogen free extract and crude fiber. To have replicated data composite sampling was performed.

Sample preparation: Fresh samples of different camel browse vegetations from respective location viz Mithi, Tando Allahyar and Thatta districts were dried for overnight at $65{ }^{\circ} \mathrm{C}$ in air-circulation oven. Samples so obtained were ground to $1 \mathrm{~mm}$ particle size using Wiley mill. Dried and ground samples were stored in air tight containers till further analysis (AOAC, 2000).
Analysis of major nutrients: Moisture percent was analyzed using evaporation method as reported by (AOAC, 2000). Dry matter of sample was analyzed using similar method as for the moisture, only calculation formula differed (AOAC, 2000). Total organic matter among camel browse vegetations was computed by difference method (AOAC, 2000). Ether extract content was determined through Soxhlet method (AOAC, 2000). Crude protein was determined using nitrogen level of sample as reported by Kjeldhal method (BSI, 1990). Crude fiber was determined using VanSoest method (AOAC, 2000). Difference method as recommended by AOAC, (2000) was used for computing the nitrogen free extract. Total carbohydrate was computed using formula suggested by (AOAC, 2000). Inorganic/mineral (ash) matter content was examined using Gravimetric method (AOAC, 2000).

Statistical analysis: A computerized statistical package i.e. Student Edition of Statistix (SXW), Version 8.1 (Copyright 2005, Analytical Software, USA) was applied to assess the data. Statistical procedure of completely randomized analysis of variance (ANOVA) under linear models was used to observe the significant variation among the variables within district as well as between vegetations, and in case of the significant difference found among the means, the least significant difference (LSD) test was applied (Gomez and Gomez, 1984).

\section{RESULTS AND DISCUSSION}

Influence of location on moisture and dry matter contents: Results mentioned in the Table- 1 reveals significant influence of location (desert, irrigated and costal mangroves) on the moisture as well as dry matter contents of all five naturally grown vegetations viz Acacia nilotica, Ziziphus nummularia, Prosopis juliflora, Salvadora oleiodes and Capparis deciduas. It was observed that the desert district (Mithi) had negative effect on the moisture content, where Acacia nilotica, Ziziphus nummularia, Prosopis juliflora, Salvadora oleiodes and Capparis deciduas pertained comparatively lowest $(\mathrm{P}<0.05)$ moisture content $(27.95,20.45,44.55$, 64.45 and $55.95 \%$, respectively), while Acacia nilotica, Ziziphus nummularia, Prosopis juliflora, Salvadora oleiodes and Capparis deciduas at irrigated district (Tando Allahyar) revealed the significantly $(\mathrm{P}<0.05)$ highest moisture content $(58.95,67.55,67.75,71.35$ and $63.55 \%$ respectively). Moisture content in Acacia nilotica at irrigated district (Tando Allahyar), Ziziphus nummularia, Prosopis juliflora, Salvadora oleiodes and Capparis deciduas at coastal district (Thatta) was recorded at moderate level $(51.10,55.95,51.10,70.15$ and $58.90 \%$, respectively). The impact of location on moisture contents of different vegetations appeared vice versa to dry matter contents. Desert location (Mithi) 
showed negative influence on moisture, where considerably $(\mathrm{P}<0.05)$ lowest moisture level was noted, while at irrigated area (Tando Allahyar) comparatively highest moisture content was observed. It is of interest to note that the moisture contents in different vegetations under current investigation were noted either inline or disagree with other reported studies. Moisture content of Acacia nilotica, Ziziphus nummularia, Capparis deciduas in the current study did not appear in line with the reported studies of different authors (Abdulrazak et al., 2001; Towhidi and Zhandi., 2007; Ashraf et al., 2013; Ullah et al., 2013; Abdullah et al., 2017; Farooq et al., 2018). Regarding Prosopis juliflora and Salvadora oleiodes our reports were in accordance with different reported studies (Murray et al., 2000; Mabrouk et al., 2008; El-Amier and Abdullah, 2015; Samreen et al., 2016).

Results regarding the total dry matter contents appeared vice versa to the moisture content (Table-1). Desert district (Mithi) significantly $(\mathrm{P}<0.05)$ favored dry matter content, where Acacia nilotica, Ziziphus nummularia, Prosopis juliflora, Salvadora oleiodes and Capparis deciduas were found rich in dry matter contents (72.05, 79.55, 55.45, 35.55 and $44.05 \%$, respectively), however coastal area (Thatta) did not support the dry matter, where it was recorded significantly $(\mathrm{P}<0.05)$ at bottom level $(41.05,32.45,32.25,28.65$ and $36.45 \%$, respectively). It is noteworthy the plant species, seasonal variation, environmental conditions like location, soil condition, water logging system and weather (dry, moderate and humid) had significant impact on nutrients composition. For instance, Mithi district at desert zone had sandy soil with dry weather significantly $(\mathrm{P}<0.05)$ favored the dry matter contents. However, environment of district Thatta (coastal zone) with recliminated soil and humid weather and Tando Allahyar (irrigated zone) with irrigated soil with moderate weather did not favor the dry matter contents (Table-1). These results are in agreement with (El-Amier and Abdullah 2015, Chiofalo et al., 2018 and Heuzé et al., 2016).

Results mentioned in Table- 1 further reveal that location did not show significant influence on organic as well as inorganic matter contents of Ziziphus nummularia, Prosopis juliflora and Capparis deciduas. Percent of organic and inorganic matter in Ziziphus nummularia, Prosopis juliflora and Capparis deciduas at desert district (Mithi) (90.65 and 9.35\%. 87.70 and $12.30 \%, 91.95$ and $8.05 \%$, respectively), at irrigated district (Tando Allahyar) (89.15 and 10.85\%, 92.35 and $7.65 \%, 88.90$ and $11.10 \%$, respectively) and at coastal district (Thatta) (89.75 and 10.25\%, 93.05 and 6.95\%, 92.75 and $7.25 \%$, respectively) found statistically similar $(\mathrm{P}>0.05)$ to one another. In case of Acacia nilotica, irrigated district (Tando Allahyar) and coastal district (Thatta) did not show any significant effect on organic matter ( 88.85 and $92.65 \%$, respectively) and inorganic matter (11.15 and 7.35\%, respectively). However, percent of organic and inorganic matter in Acacia nilotica at coastal and irrigated locations varied significantly $(\mathrm{P}<$ $0.05)$ from the desert location (72.85 and $27.15 \%$, respectively). Results further reveal significant $(\mathrm{P}<0.05)$ influence of location on organic and inorganic matter of Salvadora oleiodes, where irrigated district (Tando Allahyar) more favored the organic matter $(79.80 \%)$, while desert district (Mithi) supported inorganic matter $(40.60 \%)$. However, the influence of coastal environment (Thatta) remained at moderate level, where percent of organic and inorganic matter in Salvadora oleiodes was recorded 67.40 and $32.60 \%$, respectively (Table-1).

Influence of location on crude protein content: Crude protein contents of Ziziphus nummularia, Salvadora oleiodes, and Capparis deciduas at irrigated area (17.80, 20.05 and $22.79 \%)$ versus coastal $(17.60,19.65$ and $22.50 \%)$ did not show any significant $(\mathrm{P}>0.05)$ variation. Further, Prosopis juliflora at Tando Allahyar (irrigated) and Mithi (desert) districts (12.12 and 12.45\%, respectively) also did not show any significant variation $(\mathrm{P}>0.05)$. There were significant $(\mathrm{P}<0.05)$ difference in crude protein contents of Ziziphus nummularia, Salvadora oleiodes and Capparis deciduas at Tando Allahyar (irrigated) compared to (desert) district (17.80, 20.05 and $22.29 \%$ versus $15.36,13.17$ and $21.94 \%$, respectively) (Figure-1). The environment of Tando Allahyar (irrigated) district favored the crude protein contents of Acacia nilotica, where it was recorded comparatively $(\mathrm{P}<0.05)$ high $(12.07 \%)$ followed by Thatta (coastal) district (10.97\%), whereas environment of Mithi (desert) district did not support the crude protein content of Acacia nilotica (6.68\%).

Influence of location on ether extract content: Results regarding the influence of location on the ether extract contents of camel browse vegetations are illustrated in the Figure-2. Significant $(\mathrm{P}<0.05)$ effect of location/ environment was observed on the ether extract content of camel browse vegetations, whereby Ziziphus nummularia, Prosopis juliflora, Salvadora oleiodes and Capparis deciduas sampled from Tando Allahyar (irrigated) district pertained significantly $(\mathrm{P}<0.05)$ highest ether extract contents $(3.05,3.55,1.06$ and $2.55 \%$, respectively) followed by Thatta (coastal) $(2.05$, $2.55,0.60$ and $2.10 \%$, respectively). It was further noted that environment of Mithi (desert) supported the ether extract content of Ziziphus nummularia, where its concentration appeared considerably $(\mathrm{P}<0.05)$ higher (3.55\%). However, Tando Allahyar (irrigated) did not favor the ether extract content of Ziziphus nummularia, where its level fall to low (2.00\%). On other hand, at Thatta (coastal), the ether extract contents of Acacia nilotica was found at intermediate level (3.10\%). Results of current study found in line with reports of different authors (Towhidi, 2009; Mohsen et al., 2011; Chandra 
and Mali et al., 2014; Mabrouk, 2008; Rasool et al., 2017; El-Amier and Abdullah, 2015; Abdullah et al., 2017; Farooq et al., 2018). The desert area supported the ether extract content of Acacia nilotica, while irrigated area did not favor. These observed results are in line with different studies (Abdulrazak et al., 2001; Shawn et al., 2001; Towhidi and Zhandi, 2007; Mabrouk et al., 2008; Mohsen et al., 2011; Ashraf et al., 2013; Chandra and Mali, 2014; El-Amier and Abdullah, 2015; Abdullah et al., 2017; Farooq et al., 2018). Further, percent of ether extract in Salvadora oleiodes recorded in current study was found somewhat different from reported studies (Ullah et al., 2013; Samreen et al., 2016; Rasool et al., 2017).

Influence of location on carbohydrate content: The concentration of nitrogen free extract and total carbohydrate contents in Acacia nilotica, Ziziphus nummularia, Prosopis juliflora, Salvadora oleiodes and Capparis deciduas, although varied with location, but difference among them existed statistically nonsignificant $(\mathrm{P}>0.05)$. Acacia nilotica at Mithi and Salvadora oleiodes at Tando Allahyar showed significant $(\mathrm{P}<0.05)$ variation compared to Thatta (Table-2). Nitrogen free extract and total carbohydrate contents of Acacia nilotica at Tando Allahyar (irrigated) (55.14 and $74.79 \%$, respectively) and Thatta (coastal) (54.23 and $78.58 \%$, respectively) district found relatively similar but appeared significantly $(\mathrm{P}<0.05)$ high from that of observed at Mithi (desert) (39.17 and 62.62\%, respectively). The nitrogen free extract content and total carbohydrate of Salvadora oleiodes at Mithi (desert) district (24.94 and 45.74\%, respectively) and Thatta (23.36\% and $47.16 \%$ respectively) did not differ from one another, but compared to Tando Allahyar (35.40 and $58.15 \%$, respectively) the difference was significant $(\mathrm{P}<$ $0.05)$. Results shown in the Table- 2 reveal significant influence of location on crude fiber contents of all plants viz Acacia nilotica, Ziziphus nummularia, Prosopis juliflora, Salvadora oleiodes and Capparis deciduas investigated under present study. Crude fiber content of Acacia nilotica (24.35\%) and Prosopis juliflora (22.65\%) at Thatta (costal), Ziziphus nummularia (24.50\%), Prosopis juliflora (23.95\%) and Capparis deciduas $(27.65 \%)$ at Mithi (desert) were found comparatively $(\mathrm{P}<$ 0.05) higher contrast to Tando Allahyar (irrigated) district. Further, it was noted that the environment of Thatta (coastal) favored the concentration of crude fiber in Salvadora oleiodes though appeared significantly $(\mathrm{P}<$ $0.05)$ high (23.80\%), while desert (Mithi) location did not support it $(20.80 \%)$. The concentration of crude fiber content in Acacia nilotica (23.45\%) at Mithi (desert),
Salvadora oleiodes (22.75\%) at Tando Allahyar (irrigated) and Ziziphus nummularia (23.15\%), Prosopis juliflora (22.65\%) and Capparis deciduas (26.65\%) at Thatta (coastal) was recorded at moderate level. Findings of (Malik and Nath, 1970) regarding total carbohydrate content in Ziziphus nummularia suported the results of current study, while Bwai et al. (2015), Nazar et al. (2018) and Ashraf et al. (2013) disagreed with current results of total carbohydrate in Acacia nilotica and Capparis deciduas. Murray et al. (2000), Rathore (2009) and Mohsen et al. (2011) reported relatively similar total carbohydrate in Salvadora oleiodes as recorded in current study. Furthermore, it could be argued that environment of localities had significant impact on the percent of nitrogen free extract and total carbohydrate contents of different vegetations under present investigation. For instance, Acacia nilotica at Tando Allahyar (irrigated) and Thatta (coastal) districts found relatively similar but differed from those of observed at Mithi (desert). Similarly, the concentrations of above variables in Salvadora oleiodes at Mithi (desert) and Thatta districts did not vary from one another but varied significantly (P $<0.05)$ from those of observed at Tando Allahyar. It is also interesting to note that the environment of different localities revealed significant influence on crude fiber contents of plants viz Acacia nilotica, Ziziphus nummularia, Prosopis juliflora, Salvadora oleiodes and Capparis deciduas (Table-2). Crude fiber content of Acacia nilotica and Prosopis juliflora at Thatta (coastal), Ziziphus nummularia, Prosopis juliflora and Capparis deciduas at Mithi (desert) appeared significantly $(\mathrm{P}<$ 0.05) higher compared to Tando Allahyar (irrigated) district.

Acknowledgments: Author and co-authors are thankful to the Department of Animal Nutrition, Sindh Agriculture University, Tando jam, including its all staff member for providing research facility and conducive environment

Conflict of interest: The authors declare no conflict of interest. Author alone is responsible for the content and writing of this manuscript

Conclusion: Current study concludes that prominent impact of location occurs on most of the nutrients in different camel browse vegetations. Desert area supports the dry matter, inorganic matter and ether extract contents. The organic matters and crude protein contents are more favored at irrigated area. Influence of location on nitrogen free extract and total carbohydrate contents remains non prominent at irrigated and coastal areas. However, crude fiber is favored at coastal area. 
Table 1. Influence of location on moisture and dry matter content among camel browse vegetations.

\begin{tabular}{|c|c|c|c|c|c|}
\hline \multirow[b]{2}{*}{ Location } & \multirow[b]{2}{*}{ Camel browse vegetations } & \multirow[b]{2}{*}{$\begin{array}{l}\text { Moisture } \\
\quad(\%)\end{array}$} & \multicolumn{3}{|c|}{ Dry matter } \\
\hline & & & $\begin{array}{l}\text { Total } \\
(\%)\end{array}$ & $\begin{array}{c}\text { Organic matter } \\
\text { (\% over dry matter) }\end{array}$ & $\begin{array}{c}\text { Inorganic matter } \\
\text { (\% over dry matter) }\end{array}$ \\
\hline \multirow{7}{*}{ Mithi } & Acacia nilotica & $27.95^{j}$ & $72.05^{\mathrm{b}}$ & $72.85^{\mathrm{c}}$ & $27.15^{\mathrm{b}}$ \\
\hline & Ziziphus nummularia & $20.45^{\mathrm{k}}$ & $79.55^{\mathrm{a}}$ & $90.65^{\mathrm{a}}$ & $9.35^{\mathrm{d}}$ \\
\hline & Prosopis juliflora & $44.55^{\mathrm{i}}$ & $55.45^{\mathrm{c}}$ & $87.70^{\mathrm{a}}$ & $12.30^{\mathrm{d}}$ \\
\hline & Salvadora oleiodes & $64.45^{\mathrm{d}}$ & $35.55^{\mathrm{h}}$ & $59.40^{\mathrm{d}}$ & $40.60^{\mathrm{a}}$ \\
\hline & Capparis deciduas & $55.95^{\mathrm{g}}$ & $44.05^{\mathrm{e}}$ & $91.95^{\mathrm{a}}$ & $8.05^{\mathrm{d}}$ \\
\hline & Acacia nilotica & $51.10^{\mathrm{h}}$ & $48.90^{\mathrm{d}}$ & $88.85^{\mathrm{a}}$ & $11.15^{\mathrm{d}}$ \\
\hline & Ziziphus nummularia & $67.55^{\mathrm{c}}$ & $32.45^{\mathrm{i}}$ & $89.15^{\mathrm{a}}$ & $10.85^{\mathrm{d}}$ \\
\hline \multirow[t]{5}{*}{ Tando Allahyar } & Prosopis juliflora & $67.75^{\mathrm{c}}$ & $32.25^{\mathrm{i}}$ & $92.35^{\mathrm{a}}$ & $7.65^{d}$ \\
\hline & Salvadora oleiodes & $71.35^{\mathrm{a}}$ & $28.65^{\mathrm{k}}$ & $79.80^{\mathrm{b}}$ & $20.20^{\mathrm{c}}$ \\
\hline & Capparis deciduas & $63.55^{\mathrm{e}}$ & $36.45^{\mathrm{g}}$ & $88.90^{\mathrm{a}}$ & $11.10^{\mathrm{d}}$ \\
\hline & Acacia nilotica & $58.95^{\mathrm{f}}$ & $41.05^{\mathrm{f}}$ & $92.65^{\mathrm{a}}$ & $7.35^{\mathrm{d}}$ \\
\hline & Ziziphus nummularia & $55.95^{\mathrm{g}}$ & $44.05^{\mathrm{e}}$ & $89.75^{\mathrm{a}}$ & $10.25^{\mathrm{d}}$ \\
\hline \multirow[t]{3}{*}{ Thatta } & Prosopis juliflora & $51.10^{\mathrm{h}}$ & $48.90^{\mathrm{d}}$ & $93.05^{\mathrm{a}}$ & $6.95^{\mathrm{d}}$ \\
\hline & Salvadora oleiodes & $70.15^{b}$ & $29.85^{\mathrm{j}}$ & $67.40^{\mathrm{c}}$ & $32.60^{\mathrm{b}}$ \\
\hline & Capparis deciduas & $58.90^{f}$ & $41.10^{\mathrm{f}}$ & $92.75^{\mathrm{a}}$ & $7.25^{\mathrm{d}}$ \\
\hline LSD (0.05) & & 0.2696 & 0.2696 & 5.7644 & 5.7644 \\
\hline $\mathrm{SE} \pm$ & & 0.1265 & 0.1265 & 2.7044 & 2.7044 \\
\hline
\end{tabular}

Table 2. Influence of location on carbohydrate content of camel browse vegetations at Mithi, Tando Allahyar and Thatta.

\begin{tabular}{|c|c|c|c|c|}
\hline \multirow[b]{2}{*}{ Location } & \multirow[b]{2}{*}{ Camel browse vegetations } & \multicolumn{3}{|c|}{ Carbohydrate } \\
\hline & & $\begin{array}{c}\text { Nitrogen free extract } \\
(\%)\end{array}$ & $\begin{array}{c}\text { Crude fiber } \\
(\%)\end{array}$ & $\begin{array}{c}\text { Total } \\
(\%)\end{array}$ \\
\hline \multirow{7}{*}{ Mithi } & Acacia nilotica & $39.17^{\mathrm{fg}}$ & $23.45^{\mathrm{f}}$ & $62.62^{\mathrm{ef}}$ \\
\hline & Ziziphus nummularia & $48.95^{\mathrm{bc}}$ & $24.50^{\mathrm{d}}$ & $73.45^{\mathrm{a}-\mathrm{c}}$ \\
\hline & Prosopis juliflora & $49.75^{\mathrm{a}-\mathrm{c}}$ & $23.95^{\mathrm{e}}$ & $73.70^{\mathrm{a}-\mathrm{c}}$ \\
\hline & Salvadora oleiodes & $24.94^{\mathrm{h}}$ & $20.80^{\mathrm{j}}$ & $45.74^{\mathrm{g}}$ \\
\hline & Capparis deciduas & $40.92^{\mathrm{e}-\mathrm{g}}$ & $27.65^{\mathrm{a}}$ & $68.57^{\mathrm{cd}}$ \\
\hline & Acacia nilotica & $55.14^{\mathrm{a}}$ & $19.65^{\mathrm{k}}$ & $74.79^{\mathrm{ab}}$ \\
\hline & Ziziphus nummularia & $45.35^{\mathrm{c}-\mathrm{e}}$ & $22.95^{\mathrm{gh}}$ & $68.30^{\mathrm{c}-\mathrm{e}}$ \\
\hline \multirow[t]{5}{*}{ Tando Allahyar } & Prosopis juliflora & $54.89^{\mathrm{a}}$ & $21.80^{\mathrm{i}}$ & $76.69^{a}$ \\
\hline & Salvadora oleiodes & $35.40^{\mathrm{g}}$ & $22.75^{\mathrm{h}}$ & $58.15^{\mathrm{f}}$ \\
\hline & Capparis deciduas & $37.76^{\mathrm{fg}}$ & $25.80^{\mathrm{c}}$ & $63.56^{\mathrm{d}-\mathrm{f}}$ \\
\hline & Acacia nilotica & $54.23^{\mathrm{ab}}$ & $24.35^{\mathrm{d}}$ & $78.58^{\mathrm{a}}$ \\
\hline & Ziziphus nummularia & $46.95^{\mathrm{cd}}$ & $23.15^{\mathrm{fg}}$ & $70.10^{\mathrm{bc}}$ \\
\hline \multirow[t]{3}{*}{ Thatta } & Prosopis juliflora & $54.14^{\mathrm{ab}}$ & $22.65^{\mathrm{h}}$ & $76.79^{a}$ \\
\hline & Salvadora oleiodes & $23.36^{\mathrm{h}}$ & $23.80^{\mathrm{e}}$ & $47.16^{\mathrm{g}}$ \\
\hline & Capparis deciduas & $41.50^{\mathrm{d}-\mathrm{f}}$ & $26.65^{\mathrm{b}}$ & $68.15^{\mathrm{c}-\mathrm{e}}$ \\
\hline LSD (0.05) & & 5.5763 & 0.3064 & 5.6856 \\
\hline $\mathbf{S E} \pm$ & & 2.6162 & 0.1438 & 2.6675 \\
\hline
\end{tabular}




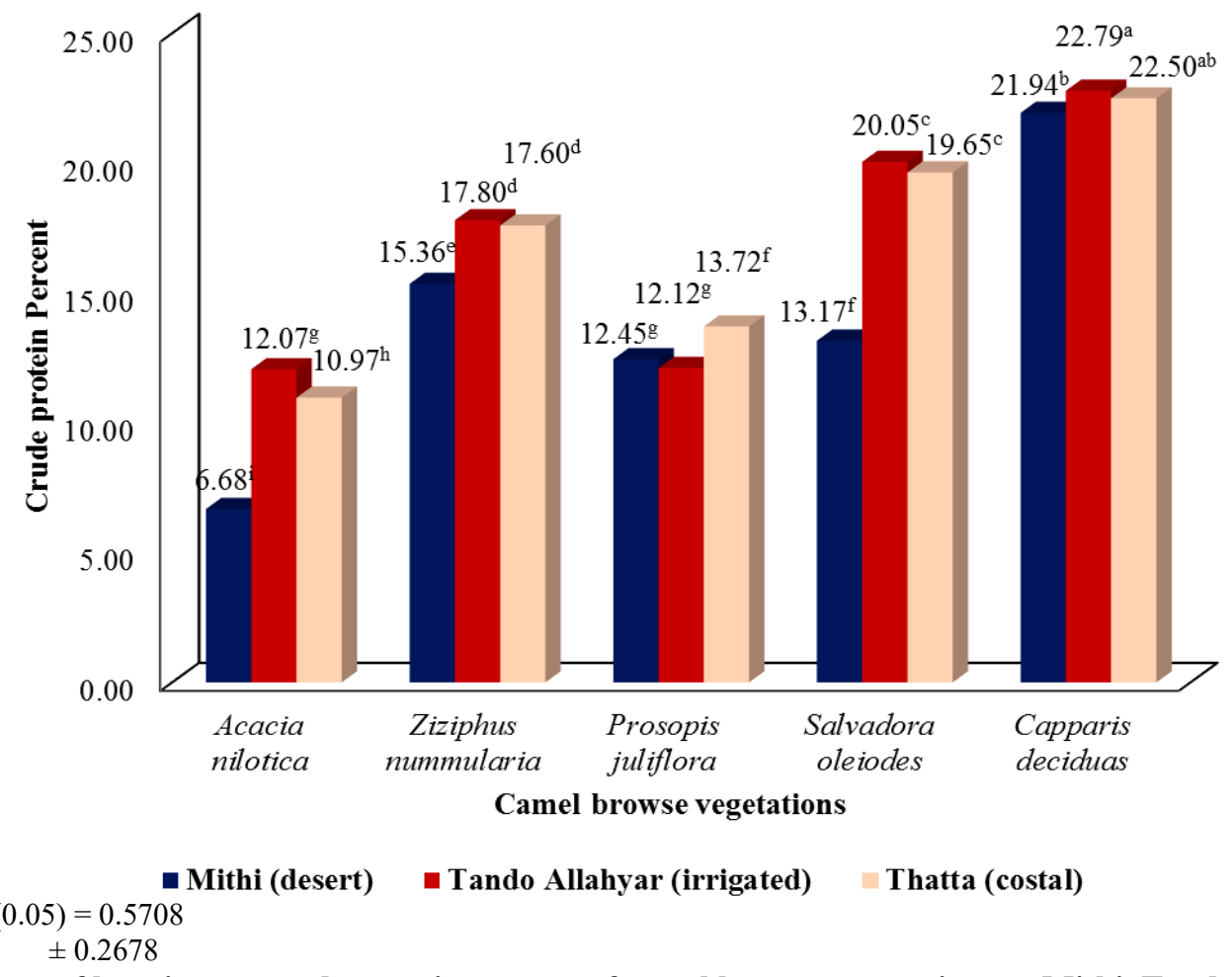

Fig. 1. Influence of location on crude protein content of camel browse vegetations at Mithi, Tando Allahyar and Thatta.

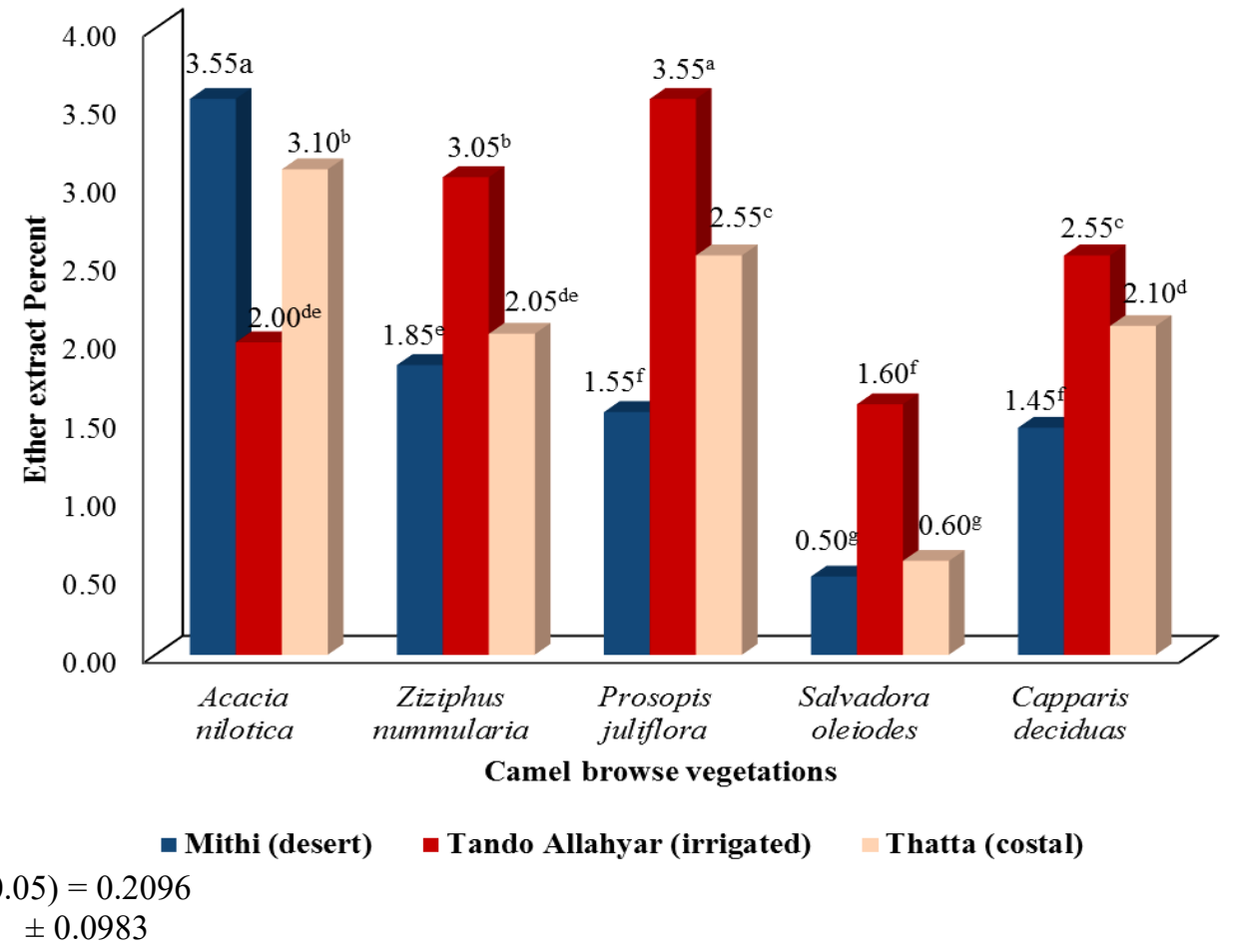

Fig. 2. Influence of location on ether extract content of camel browse vegetations at Mithi, Tando Allahyar and Thatta 


\section{REFERENCES}

A.O.A.C (2000). Official methods of analysis. Association of Official Analytical Chemists International. Maryland, USA.

Abdullah, M., M. Rafay, N. Sial, F. Rasheed, M. F. Nawaz, W. Nouman, I. Ahmad, T. Ruby, and S. Khalil (2017). Determination of forage productivity, carrying capacity and palatability of browse vegetation in arid rangelands of cholistan desert (pakistan). Appl. ecology and environ. Res. 15(4): 623-637.

Abdullah, M., M. Rafay, T. Hussain, H. Ahmad, U. Tahir, F. Rasheed, T. Ruby, and S. Khalil (2017). Nutritive potential and palatability preference of browse foliage by livestock in arid rangelands of Cholistan desert (Pakistan). The J. Anim. and Plant Sci., 27 (5): 1656-1664.

Abdulrazak, S. A., E. A. Orden, T. Ichinohe and T. Fujihara (2001). Chemical composition, phenolic concentration and in vitro gas production characteristics of selected Acacia fruits and leaves. Asian Australasian. J. Anim. Sci. 13(7):935-940.

Ashraf, M. A., M. Karamat, A. Wajid, A. K. Qureshi, and M. Gharibreza (2013). Chemical constituents of Haloxylon salicornicum plant from Cholistan desert, Bahawalpur. Pakistan J. Food, Agri. and Environment. 11(3-4): 1176-1182.

BSI (1990). Methods of Testing the food. British Standards Institution: London, UK.

Bwai, M. D., D. Uzama, S. Abubakar, O. O. Olajide, P. P. Ikokoh, and J. Magu (2015). Proximate, elemental, phytochemical and anti-fungal analysis of Acacia nilotica fruit. Pharmaceutical and Biol. Evaluations. 2(3): 52-59.

Chandra, J and M. C. Mali (2014). Nutritional evaluation of top five fodder tree leaves of mimosaceae family of arid region of Rajasthan. Int. J. Inn. Res. Rev. 2(1): 14-16.

Chaudhary, S.A. and H. N. L. Houérou (2006). The rangelands of the Arabian Peninsula. Science et changements planétaires/Sécheresse. 17(1): 179194.

Chiofalo, B., V. L. Presti, A. D'Agata, R. Rao, G. Ceravolo, and F. Gresta (2018). Qualitative profile of degummed guar (Cyamopsis tetragonoloba L.) seeds grown in a Mediterranean area for use as animal feed. J. of Anim. Phys. and Anim. Nutri. 102(1): 260-267.

Dong, S., L. Wen, L. Zhu, and X. Li (2009). Implication of coupled natural and human systems in sustainable rangeland ecosystem management in $\mathrm{HKH}$ region. Front. Earth Sci. China. Higher Education Press and Springer-Verlag. 4(1): 4250
El-Amier, Y. A. and T. J. Abdullah (2015). Evaluation of nutritional value for four kinds of wild plants in Northern sector of Nile Delta, Egypt. Open J. Appl. Sci. 5(7): 393-402.

Farooq, M. U., R. U. K. Marwat, I. A. Qamar, S. Ahmad, A. Razaq and U. A. Tiwana (2018). Seasonal variation in nutritional characteristics of forage species in Rakh Choti Dalana in District Dera Ghazi Khan "Pakistan. Basic Res. J. Agri. Sci. and Rev. 6(3):21-26.

Gomez, K and A. Gomez (1984). Statistical procedures for agricultural research institute. Second edition, Los Banos Philipines: Jhon Wiley Sons Inc

Heuzé V., H. Thiollet, G. Tran, P. Hassoun, D. Bastianelli, F. Lebas (2016). Gum arabic tree (Acacia senegal). Feedipedia, a programme by INRA, CIRAD, AFZ and FAO. http://www.feedipedia.org/node/342. Retrived on July 4, 2018, 17:00.

Iqbal, A (2005). A socio-economic profile of camels in Pakistan with special emphasis on management and production aspects. Proc. International Workshop on Camel Research and Development. Wad Medani, Gezira State, Sudan:45-50.

Iqbal, A. and B. B. Khan (2001). Feeding behaviour of camel----Review. Pakistan J. Agri. Sci., 38: 5863.

Joshi, S., R.M. Shrestha, M. Ismail, F.M. Qamer, A.W Jasra, Z. Dan, and W. Ning (2013). Highaltitude rangelands and Land Use Practices in the Karakoram-Pamir Landscape. ICIMOD. http://lib.icimod.org/record/28844/files/4HAR.p df

Mabrouk, H., E. Hilmi, and M. Abdullah (2008) Nutritional value of Prosopis juliflora pods in feeding nile tilapia (Oreochromis niloticus) fries. Arab Gulf J. Scientific Res. 26(1-2): 49-62.

Majeed, A., M. Azam and D. A. Mumtaz (2002). Drought and Water Management Strategies in Pakistan. Proceedings of SAARC Workshop on Drought and Water Management Strategies. Pakistan Council of Research in Water Resources, Islamabad, Pakistan.

Malik, N. S and K. Nath (1970). Chemical composition and nutritive value of green pala (Ziziphus nummularia) leaves. Ind. J. Anim. Sci. 40: 4145.

Mohsen, M. K., G. S. El-Santiel, H. M. A. Gaafar, H. M. El-Gendy and E. A. El-Beltagi (2011). Nutritional evaluation of berseem. 2. Effect of nitrogen fertilizer on berseem fed as silage to goats. Archiva Zootechnica. 14(3): 21-31.

Murray, S. S., M. J. Schoeninger, H. T. Bunn, T. R. Pickering, J. A. Marlett (2000). Nutritional 
composition of some wild plant foods and honey used by Hadza foragers of Tanzania. J. food comp. and Anal. 14(1):3-13.

Nazar, H., A.K. Mohammed, O.A. Ibrahim, Y.M. Ishiyaku, S.A, Ahmed and M Abdullah (2018). Nutritional composition of some forage species consumed by one-humped camels (camelus dromedarius) in zaria sub-humid region of nigeria. J. Anim. Prod. Res. 29: 365-370.

Rasool, F., M. Ishaque, S. Yaqoob, and A. Tanveer (2017). Chemical composition and ethnobotanical uses of Acacia jacquemontii Benth. in the Thal desert in Pakistan. Bois et Forêts des Tropiques. 331:1-10.

Rathore, M (2009) Nutrient content of important fruit trees from arid zone of Rajasthan. J. Hort. and Forest. 1(7):103-108.

Samreen U., M. Ibrar, L. Badshah and B. Ullah (2016). Nutritional and Elemental Analysis of Some Selected Fodder Plants of Darazinda FRDI Khan, Pakistan Adv. P. Agri. Res. 4(1): 00127.

Shaheen, G (2009). Seasonal variation in nutritional and anti-nutritional components of native shrubs and trees grown in Hazargangi Chiltan National Park, Karkhasa and Zarghoon, PhD Dissertation. Quetta: University of the Balochistan.

Shawn, T., P. Okullo, D. Hafashimana, and D.M. Byabashaija (2001). Diversity and composition of trees and shrubs in Kasagala forest: A semiarid savannah woodland in Central Uganda. African J. Ecol. 48(1): 111-118.

Tennigkeit, T. and A. Wilkes (2008). An Assessment of the Potential for Carbon Finance in Rangelands. Working Paper no. 68. World Agroforestry Center, Beijing, China

Towhidi, A (2009). Nutritive value of some herbages for dromedary camel in Iran. Pakistan J. Biol. Sci. 10(1):167-170.

Towhidi, A. and M. Zhandi (2007). Chemical composition, in vitro digestibility and palatability of nine plant species for dromedary camels in the province of Semnan. Iran. Egypt. J. Biol., 9(1): 47-52.

Ullah, Z., M. K. Baloch, J. A. Khader, I. B. Baloch, R. Ullah, M. N. AbdEIslam, and S. Noor (2013). Proximate and nutrient analysis of selected medicinal plants of Tank and South Waziristan area of Pakistan. African J. of Pharmacy and Pharmacology. 7(5):179-184.

Younas, M. and M. Yaqoob (2005). Feed resources of livestock in the Punjab, Pakistan. Livestock Research for Rural Development. 17, Art. \#18. Retrieved June 7, 2018, from http://www.lrrd.org//rrd17/2/youn17018.htm. 